\title{
Abundance of aposematic patterns in hooded skunk, Mephitis macroura
}

\section{Abundancia de los patrones aposemáticos en el zorrillo listado sureño, Mephitis macroura}

\author{
Alina Gabriela Monroy-Gamboa ${ }^{1 *}$, Mario C. Lavariega², and Dagoberto Ramos-Méndez² \\ ${ }^{1}$ Centro de Investigaciones Biológicas del Noroeste, S. C. Av. Instituto Politécnico Nacional 195, C. P. 23096. La Paz, Baja California Sur, \\ México. E-mail: beu ribetzin@hotmail.com (AGM-G). \\ ${ }^{2}$ Centro Interdisciplinario de Investigación para el Desarrollo Integral Regional, Unidad Oaxaca, Instituto Politécnico Nacional. Hor- \\ nos 1003, C. P. 71230. Santa Cruz Xoxocotlán, Oaxaca, México. E-mail: mlavariegan@ipn.mx (MCL); dmendez 11@hotmail.com \\ (DR-M). \\ *Corresponding author
}

\begin{abstract}
Some organisms warn their predators through color patterns. This is the case of the hooded skunk, Mephitis macroura. Under the assumption that the coloration of skunks is aposematic, we analyzed the coloration patterns of a population of hooded skunks. We hypothesized that the individuals showing a more contrasting coloration, should be more abundant in open vegetation types than those with a less contrasting pelage coloration. Using camera-traps, we grouped photographs of hooded skunks showing different combinations of color patterns and determined the relative abundance of individuals by color patterns by set and habitat type. We identified 25 individuals in the study area, most of them in induced grasslands, and identified four combinations of color patterns. We found an overlap of the period of activity and space, as well as a higher abundance of the most contrasting color pattern in the most open type of vegetation, accepting our hypothesis. We contribute to a better understanding of the ecologic relations between the habitat and the possible adaptations of some species to their environment like the skunks.
\end{abstract}

Key words: Banner-bearer; camera trap; carnivores; color pattern; Mixteca region; Oaxaca.

Algunos organismos advierten a sus depredadores a través de patrones de coloración. Este es el caso del zorrillo listado sureño, Mephitis macroura. Asumimos que la coloración de los zorrillos es aposemática, por lo que el objetivo fue analizar los patrones de coloración de una población de zorrillo listado sureño. Nuestra hipótesis fue que los individuos que mostraran una coloración más contrastante serían más abundantes en tipos de vegetación abierta que aquellos con una coloración de pelaje menos contrastante. Por medio de cámaras-trampa, agrupamos las fotografías del zorrillo listado sureño mostrando diferentes tipos de combinación de los patrones de coloración y se determinó la abundancia relativa de los individuos por patrones por grupo y hábitat. Identificamos 25 individuos en el área de estudio, la mayoría en pastizales inducidos e identificamos cuatro combinaciones de patrones de coloración. Encontramos una superposición en el periodo de actividad y el espacio, así como una alta abundancia del patrón de coloración más contrastante en el tipo de vegetación más abierta, aceptando nuestra hipótesis. Se contribuye a un mayor entendimiento sobre las relaciones ecológicas entre el hábitat y la posible adaptación de las especies a su ambiente como los zorrillos.

Palabras claves: Abanderado; cámaras-trampa; carnívoros; Oaxaca; patrón de coloración; región Mixteca.

(C) 2021 Asociación Mexicana de Mastozoología, www.mastozoologiamexicana.org

Living organisms have evolved in various ways to survive, including the adoption of defense mechanisms that can be olfactory, auditory, or visual. Visually, the individual catches the attention of potential predators through a warning coloration (Cott 1940; Mochida 2011). This defense mechanism has been studied mainly in plants, invertebrates, amphibians, reptiles, birds, and some mammals (Mochida 2011; Lev-Yadun 2016; Ebersbach et al. 2020; Pinheiro-de Castro et al. 2020). In mammals, the difference in coloration is not only useful as a functional defense adaptation; it also serves as camouflage, as well as for communication or thermoregulation (Caro 2005; Lindstedt et al. 2008).
Skunks have a variety of ways to alert their predators, including auditory, olfactory, and visual mechanisms, and evidence their presence through behavioral and physical signals (Medill et al. 2011); their main predators are felids, canids, and birds of prey (Hwang and Larivière 2001). The hooded skunk (Mephitis macroura) is a small-sized carnivorous species; its coloration varies among individuals, with different proportions of black and white pelage, and a brown or reddish coloration occasionally present (Dragoo 2009). It has a large, notoriously hairy tail used as a warning banner, which can display diverse color patterns ranging from monochromatic to bicolor (Hwang and Larivière 
2001). The color pattern varies among individuals of the same species, geographic area, or population; individuals with whiter pelage are more noticeable from greater distances (Van Gelder 1968). Color patterns do not depend on sex, age, moult, or size (Van Gelder 1968; Dragoo 2009).

In skunks, color patterns can have multiple combinations, although a general pattern is evident (Van Gelder 1959). There are some studies about the relation of coloration patterns in skunks with their environment (Van Gelder 1968; Dragoo et al. 2003) but none were conducted with the hooded skunk. Under the assumption that the coloration of skunks is aposematic (conspicuous appearance to warn predators), we analyzed the coloration patterns of a population of hooded skunks living in the Mixteca region of Oaxaca, México. Our working hypothesis was that the individuals showing a more contrasting coloration, that is, aposematic, should be more abundant in open types of vegetation than those with a less contrasting pelage coloration, because the warning results more effective.

The study area is the municipality of Cosoltepec, Huajuapan de León district in the Mixteca region of the state of Oaxaca, México. Sampling was conducted from December 2013 to June 2014. We deployed a grid of 14 camera-traps with no bait within a $19.7 \mathrm{~km}^{2}$ quadrant, defined as a minimum convex polygon. Camera-traps (Cuddeback ${ }^{\circledast}, 3 \mathrm{MB}$ resolution) were placed $30 \mathrm{~cm}$ above the ground and 1.5 $\mathrm{km}$ apart, these camera-traps only take photographs, were set to operate 24 hours daily with a minimum 30 seconds delay between shots, one at the time. Image records were georeferenced on the VI land use and vegetation series map (INEGI 2016) to corroborate field data (Figure 1).

We classified hooded skunk (Mephitis macroura) photographs according to the coloration pattern using a 1-to-5 scale, where one (1) is the pattern with the least contrast and five (5) corresponds to the highest contrast (Hass 2003), as follows: 1) Shadow (Sh): pelage mostly black, may be moderate grizzly on the tail; 2 ) Hooded $(\mathrm{H})$ : all body pelage black, except for the head, which is white; 3 ) Lined (L): back generally black, showing a white stripe from the chest to the hind legs; it may or may not show secondary white stripes from behind the ears to the scapula or a thin white stripe across the scapula; 4) Silvered (S): white back from nape to tail; and 5) Banner-bearer (BB): abundant whitish pelage in all the back, with lateral stripes (Figure 2). One person did the first classification; later another person corroborated it.

The differential color pattern and particular characteristics allowed identifying individual organisms. Relative abundance was estimated as the percentage of individuals in each color category relative to the total number of

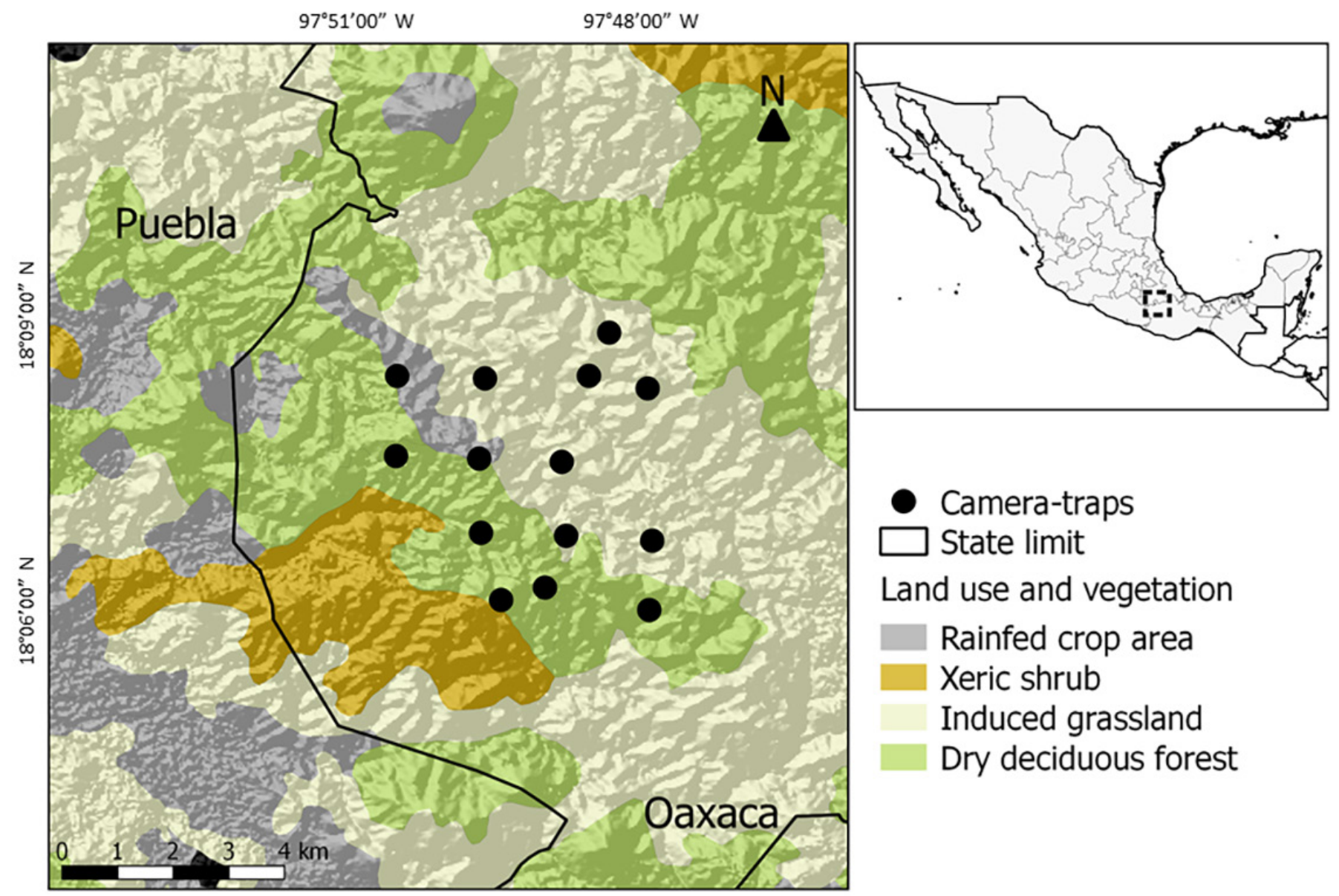

Figure 1. Geographic ubication of the camera-traps (black spots) in the different types of vegetation in Cosoltepec, Oaxaca, México. Vegetation types from INEGI (2016). 
individuals sampled. We ran an asymmetry coefficient in Microsoft Excel with the formula "Coeficiente.Asimetria.P" per type of vegetation and coloration patterns to test our hypothesis.

With a sampling effort of 2,520 camera-traps / day, we captured 40 photographs of hooded skunk, considering only 7 of the 14 camera-traps deployed (50\%; 3 placed in induced grassland, 2 in rainfed crops, and 2 in dry deciduous forest); the greatest sampling effort was done in the induced grassland.

We identified 25 individuals, which were assigned to four of the five coloration patterns (Table 1; Figure 2). Most of the individuals ( $36 \%$ ) showed the Banner-bearer coloration pattern (the one with the greatest contrast), and no individuals with the Shadow pattern (the one with the least contrast) were recorded (Table 1).

The induced grassland is the dominant habitat type in the study area; it has secondary shrubby vegetation related to the dry deciduous forest, with extensive cattle and goat farming, whose offspring can be potential prey for medium-sized carnivores. The highest number of hooded skunks (64\%) was recorded in this habitat, $50 \%$ of which were classified as Banner-bearers (Figure 3 ). The results of the asymmetry coefficient showed a positive asymmetry
Table 1. Number of individuals of hooded skunk, Mephitis macroura and relative abundance by color patterns in Cosoltepec, Oaxaca, México.

\begin{tabular}{lcc}
\hline \multicolumn{1}{c}{ Color pattern } & Individuals & Relative Abundance \\
\hline Shadow & N/D & 0 \\
Hooded & 3 & 12 \\
Lined & 8 & 32 \\
Silvered & 5 & 20 \\
Banner-bearer & 9 & 36 \\
Total & $n=25$ & 100 \\
\hline
\end{tabular}

$\mathrm{N} / \mathrm{D}=$ No Data

for induced grassland (0.816). Conversely, the rainfed crop area showed a negative asymmetry $(-0.214)$. For the dry deciduous forest the coefficient resulted zero.

In the rainfed crop area (corn, beans, and squash), characterized by sparse plant cover, no Banner-bearer individuals were recorded; this finding suggests that the rainfed crop area does not favor conspicuous individuals (Fay 2017; Fisher and Stankowich 2018). In contrast, only $8 \%$ of the individuals were recorded in the dry deciduous forest, belonging to the Lined and Banner-bearer types (Figure 3). Only a single individual (Silvered) was recaptured with the same camera-trap in induced grassland during the prerainy and rainy seasons.
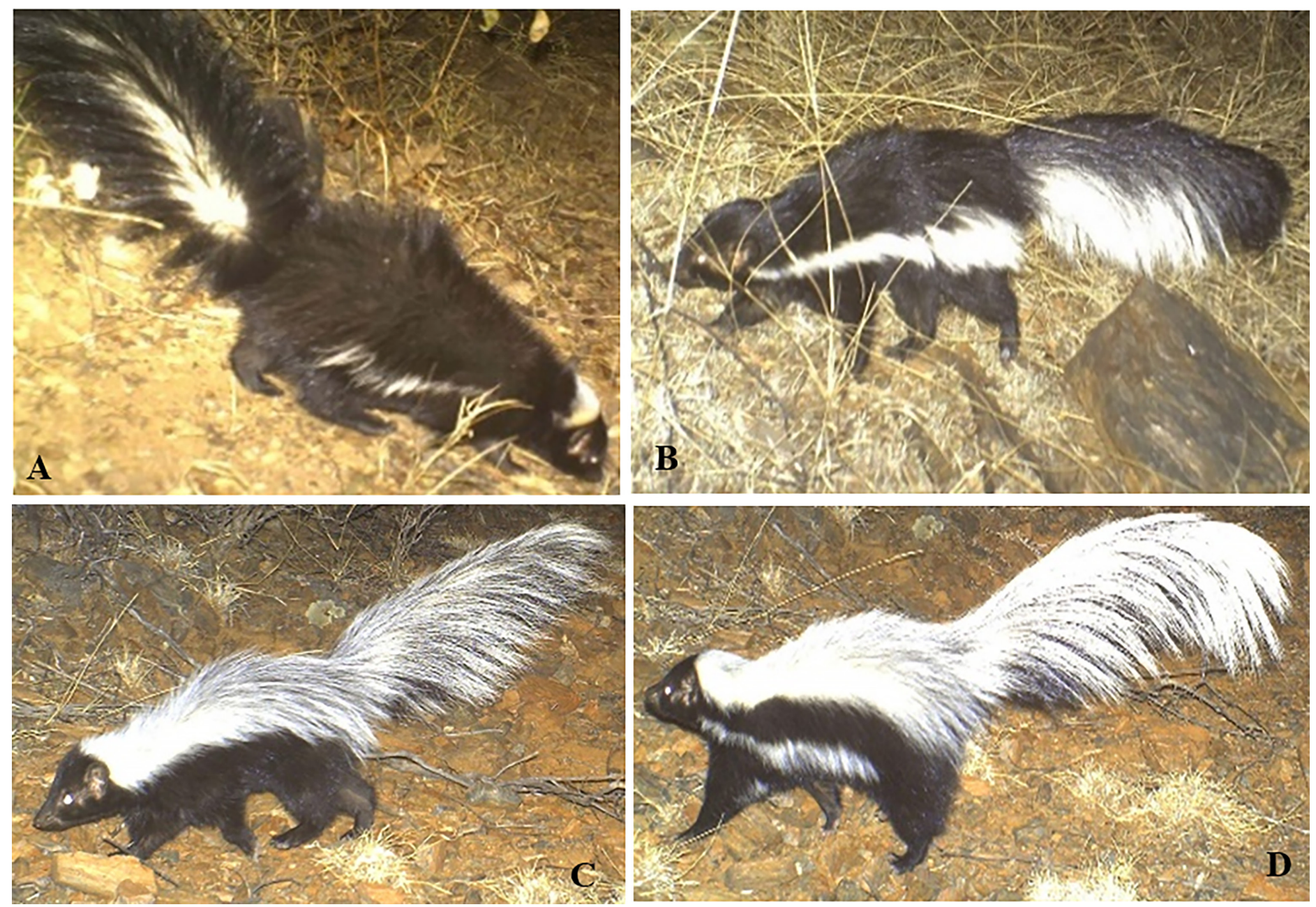

Figure 2. Color patterns of hooded skunk, Mephitis macroura in Cosoltepec, Oaxaca, México. A: Hooded; B: Lined; C: Silvered; D: Banner-bearer. 


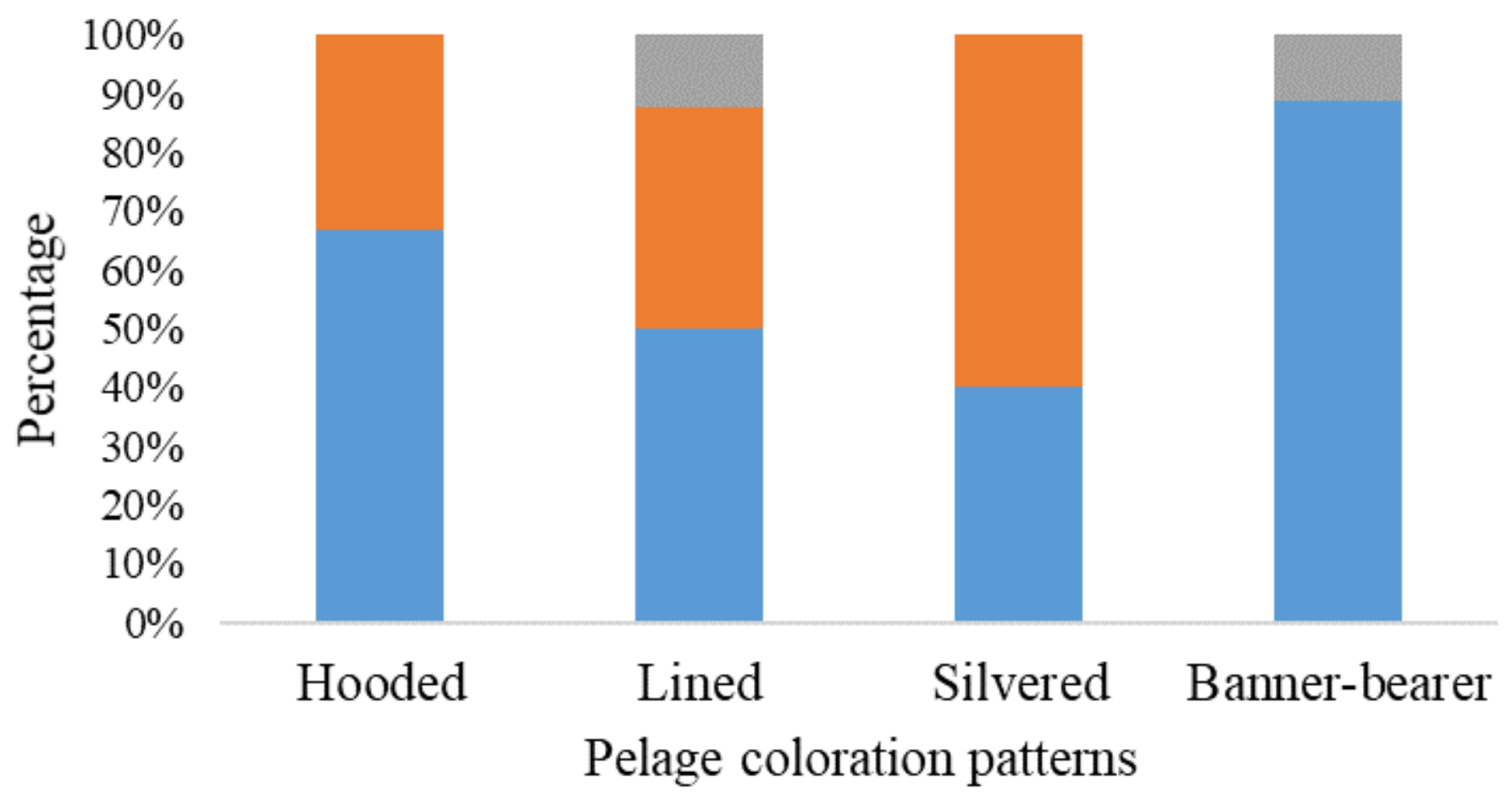

\section{Induced grassland $\quad$ Rainfed crop area $\quad$ Dry deciduous forest}

Figure 3. Percentage of individuals of hooded skunk, Mephitis macroura by vegetation types and pelage color patterns in Cosoltepec, Oaxaca, México.

The light is an important factor for the black and white species, it is documented that the striped species, like some skunk species, are easier to see in open-lighting areas (aro et al. 2013). The hooded skunks recorded display different combinations of pelage coloration patterns in the study area. The predominant coloration pattern was the Bannerbearer, the one with the greatest contrast, making individuals more conspicuous and easier to spot by predators, unlike the less aposematic Shadow monochromatic coloration, which was not recorded in the study area. Also, the Banner-bearer was the coloration pattern that defined a positive or a negative asymmetry, showing the importance of aposematism in different vegetation types, and demonstrating our hypothesis.

In our study area, Ramos-Méndez (2015) found an overlap of daily activity patterns between the hooded skunk and its potential predators (coyote and bobcat), suggesting that despite its parsimonious movement, the hooded skunk coexists with its predators, and the aposematism is effective for them. This overlap of the period of activity and space, as well as a higher abundance of the most contrasting color pattern and the lower abundance of the least contrasting pattern, suggests that the aposematic coloration of skunks serve to communicate a warning to predators, reducing the likelihood of been selected as prey. These results confirm our hypothesis that a more contrasting coloration (aposematic) are more abundant than those with a less contrasting pelage coloration, because the warning results more effec- tive. Similar findings were realized with other skunk species, they demonstrate that when they have more white fur and they were bigger, the potential predators react to noxious and avoid them (Hunter 2009; Caro et al. 2013; Mann 2018; Howell et al. 2021). Mann (2018) showed that the coloration patterns in M. mephitis have more variation in habitats with more risk of predation. These studies were conducted for terrestrial predators. Recently, a hooded skunk predation by a greater horned owl was reported by Sánchez-Rojas et al. (2021). Authors mentioned that probably the aposematism of the skunk was not effective for the raptor. It could be interesting to analyze the relation of the aposematism of skunk species with non-terrestrial predators.

Our results consider that there is an influence of the type of habitat on the degree of aposematism of the hooded skunk exists, but the sample size was remarkably reduced and the induced grassland was the type of vegetation with more sample effort. Although it seems that the least aposematic individuals were associated with sites with a higher vegetation cover, while the most conspicuous individuals tended to be more cosmopolitan. We recommend to replicate this analysis in a bigger scale. The wide distribution range of this species will be ideal to have all the types of habitats and all coloration patterns.

This contributes to the better understanding of the ecological relations between the habitat and the possible physical adaptations of some species to their environment like the skunks. 


\section{Acknowledgements}

We thank to the municipal and ejidal authorities of Cosoltepec for the permission given to develop this study in their territories. The field work was supported by Secretaría de Investigación y Posgrado, Instituto Politécnico Nacional, with a project managed by M. A. Briones-Salas. Y. M. Martínez-Ayón and B. Riveros-Lara by their valuable support on field. AGM-G thanks to Consejo Nacional de Ciencia y Tecnología (CONACyT) for her postdoctoral fellowship at Centro de Investigaciones Biológicas del Noroeste, S. C. (CVU 206047). The authors thanks to S. T. Castañeda-Álvarez that reviewed early versions of this manuscript and two anonymous reviewers that help to improve it. To M. E. Sánchez for the language edition.

\section{Literature cited}

CARo, T. 2005. The adaptative significance of coloration in mammals. BioScience 55:125-136.

Caro, T., T. Stankowich, C. Kiffner, and J. Hunter. 2013. Are spotted skunks conspicuous or criptic? Ethology Ecology \& Evolution 25:144-160.

Coтt, H. B. 1940. Adaptative coloration in animals. Metheun and Co. London, United Kingdom.

Dragoo, J.W. 2009. Nutrition and behaviour of Striped Skunks. Veterinary Clinics of North America: Exotic Animal Practice 12:313-325.

Dragoo, J. W., R. L. Honeycutt, and D. J. Schmidly. 2003. Taxonomic status of white-backed hog-nosed skunks, genus Conepatus (Carnivora: Mephitidae). Journal of Mammalogy 84:159-176.

Ebersbach, J., A. Posso-Terranova, S. Bogdanowicz, M. GómezDiaz, M. X. García-González, W. Bolívar-García, and J. Andrés. 2020. Complex patterns of differentiation and gene flow underly the divergence of aposematic phenotypes in Oophaga poison frogs. Molecular Ecology 29:1944-1956.

FAY, C. 2017. Aposematic variation and the evolution of warning coloration in mammals. M.Sc. thesis. California State University. California, U.S.A.

Fisher, K. A., AND T. S. Stankowich. 2018. Antipredator strategies of striped skunks in response to cues of aerial and terrestrial predators. Animal Behavior 143:25-34.

Hass, C. C. 2003. Ecology of Hooded and Striped Skunks in Southern Arizona. Arizona Game and Fish Department, Heritage Fund. Arizona, U.S.A.

Howell, N., C. Sheard, M. Konen, K. Brockelsby, K. Ono, and T. CARo. 2021. Aposematism in mammals. Evolution 75:2480-2493.

Hunter, J. S. 2009. Familiarity breeds contempt: effects of striped skunk color, shape and abundance on wild carnivore behaviour. Behavioral Ecology 20:1315-1322.

Hwang, Y. T., and S. LaRivière. 2001. Mephitis macroura. Mammalian Species 686:1-3.

Instituto Nacional de Estadística y Geografía (INEGI). 2016. Conjunto de datos vectoriales de la carta de Uso de Suelo y Vegetación. Escala 1:250,000 Serie VI. Conjunto Nacional. Instituto Nacional de Estadística y Geografía, México. https:// www.inegi.org.mx/temas/usosuelo/\#Descargas. Accessed in August 2, 2020.
Lev-Yadun, S. 2016. Defensive (anti-herbivory) coloration in land plants. Springer International Publishing, Switzerland.

Lindstedt, C., L. Lindström, AND J. MAPPes. 2008. Thermoregulation constrains effective warning signal expression. Evolution 63:469-478.

ManN, V. 2018. The characteristics of aposematism and noxious spray in the striped skunk (Mephitis mephitis). M. Sc. Thesis. California State University. Long Beach, California, U.S.A.

Medill, S. A., A. Renard, and S. Larivière. 2011. Ontogeny of antipredator behaviour in striped skunks (Mephitis mephitis). Ethology Ecology \& Evolution 23:41-48.

MocHIDA, K. 2011. Combination of local selection pressures drives diversity in aposematic signals. Evolutive Ecology 25:1017-1028.

Pinheiro-de Castro, E., R. Demirtas, A. Orteu, C. E. Olsen, M. Saddik, M. Zikan-Cardoso, M. Zagrobelny, and S. BaK. 2020. The dynamics of cyanide defences in the life cycle o fan aposematic butterfly: biosynthesis versus sequestration. Insect Biochemistry and Molecular Biology 116:103259.

Ramos-Méndez, D. 2015. Diversidad, actividad y uso de hábitat de carnívoros en dos sitios con diferente grado de perturbación en el municipio de Cosoltepec, Oaxaca. M. Sc. Thesis. Centro Interdisciplinario de Investigación para el Desarrollo Integral Regional-Unidad Oaxaca. Instituto Politécnico Nacional, Oaxaca, México.

Sánchez-Rojas, G., Z. K. Zepeda-Hernández, J. A. Hernández-Melo, C. A. Maciel-Mata, and J. A. Hernández-Silva. 2021. Predation of the hooded skunk, Mephitis macroura, by the great horned owl, Bubo virginianus, in the Barranca de Metztitlán Biosphere Reserve, Hidalgo, México. Therya Notes 2:105-108.

Van Gelder, R. G. 1959. A taxonomic revision of the spotted skunks (genus Spilogale). Bulletin of the American Museum of Natural History 117:229-392.

Van Gelder, R. G. 1968. The genus Conepatus (Mammalia, Mustelidae): Variation within a population. American $\mathrm{Mu}-$ seum Novitates 2322:1-38.

Associated editor: José F. Moreira-Ramírez

Submitted: August 9, 2021; Reviewed: November 4, 2021.

Accepted: November 11, 2021; Published on line: November 18, 2021. 